\title{
Between East and West: Karel Chytil as Museologist, Educator, and Art Historian
}

\author{
Pavel Šopák
}

Pavel Šopák, PhD, Associate Professor

University of Technology

Faculty of Architecture

Department of Theory

Poŕíči 273/5, Brno, 63900

Czech Republic

e-mail: sopak@fa.vutbr.cz

Muzeológia a kultúrne dedičstvo, 2020, 8:3:129-138

DOI: $10.46284 / \mathrm{mkd} .2020 .8 .3 .7$

Between East and West: Karel Chytil as Museologist, Educator, and Art Historian

Adapted version of the text presented at the colloquium organised in Prague on 12 November 2019 by the Institute of Art History of the Czech Academy of Sciences (CAS) on the 85th anniversary of PhDr. Karel Chytil's death. The text deals with the institutional and cultural political aspects of Chytil's career as an art historian, museologist, and lecturer.

Keywords: Chytil Karel, art history and historiography, Viennese school, historic preservation, history of museology, Czechoslovakia's artistic culture, museums of decorative arts

Had it not been for a few occasional texts, mainly obituaries and profiles in specialised encyclopedias, ${ }^{1}$ Karel Chytil $^{2}$ would lack any kind of recognition. It is all the more surprising that there is still no complex monograph and, at the same time, universal critique as well as fair appreciation, considering how prominent a figure he was in the field of the Czech scientific and artistic culture at the end of the nineteenth and in the first third of the twentieth centuries. This

\footnotetext{
${ }^{1}$ WIRTH, Zdeněk. Karel Chytil. In: Umèní 8, 1934. no. 1, p. 8.; Id. Karel Chytil (2. VII. 1934). In: Český časopis historický 40, 1934, pp. 662-664; BIRNBAUM, Vojtěch. Prof. Dr. Karel Chytil. In: Časopis Společnosti prátel starožitností 42, 1934, pp. 142-143; MATĚJČEK, Antonín. Karel Chytil. In: Ročenka Krubu pro pěstování dějin uméní za rok 1934. Praha, 1935, pp. 3-15; KRÁSA, Josef. Karel Chytil. In: CHADRABA, Rudolf, KRÁSA, Josef - ŠVÁCHA, Rostislav (eds.): Kapitoly z českého déjepisu uméní 1. Praha, 1986, pp. 172-180.

${ }^{2}$ Karel Chytil (1857-1934) was born in Prague. He graduated from grammar school and then he studied history and geography at the Faculty of Arts at Charles University in Prague (1875-1878). He spent the academic year 1878-1879 at the Institut für österreichische Geschichtsforschung in Vienna (1878-1879), where he attended Moritz Thausing's lectures, which resulted in him directing his focus from history to history of art. He was the head of the Museum of Decorative Arts in Prague, and a director there from 1895 to 1911. Between 1887 and 1903 he was a correspondent at k. k. Zentral-Kommission für Erforschung und Erhaltung der Kunst und historischen Denkmale in Vienna. From 1888 to 1896 he was an art history professor at the Academy of Fine Arts in Prague, and from 1911 a full professor and the head of the Institute of Art History at the Czech University in Prague, where he was employed until his retirement in 1927.
} 
text, although by no means comprehensive, was instigated by outer interest, ${ }^{3}$ and allows us to remind the reader, without claiming completeness, of one of the important, or even determining, aspects of his intellectual biography, which can be symbolically expressed by the polarity East-West. It is focused on Chytil's sociability, not the methods of his work, i.e. it is about his social contacts, institutional position, and the aspects of his public activity. Therefore, under East and West, we should imagine two cultural-historical, or better yet, cultural political contexts which meet in his biography. A fixed border between the two is represented by year 1918, when the independent country of Czechoslovakia was established, which significantly changed the symbolic validity of East and West. However, there are documents which reveal the crossing of that time boundary, and which, at the same time, corroborate it. There is a letter from 15 May 1927, addressed to Chytil by an important German scholar, Aby Warburg (1866-1929), in which he expressed his interest in certain materials from the era of Rudolf II, which he wanted to see on his trip around Germany, during which he would pass through Prague. ${ }^{4}$ This way, Warburg approached the "pre-coup" Chytil, who belonged to the late era of neo-absolutism with its integrity of fine arts in the German-speaking territory, but also Chytil as the ex-director of the Museum of Decorative Arts in Prague, and Chytil during the first stage of his life, the fame of which pervaded to the second, post-coup stage.

The focus will now be directed towards the first major stage of Chytil's career and the way East and West were thematised in that period of his life. Chytil's socio-professional status at that time, which determines the realisation of the eastern or western orientation, can be understood if we bring to mind the well-known fact that until the end of the First World War there werefrom the point of view of exclusiveness and social prestige as well as economic success_-only two types of environment where an art historian from Central Europe could find employment. The first of these was universities, and the second one central museum institutions and partly central institutions of state historic preservation. ${ }^{5}$ Drawn from the major schools of art history, ${ }^{6}$ these were art history graduates of the Viennese school, i.e. students R. Eitelberger, M. Thaussing, F. Wickhoff, A. Riegl, M. Dvořák and J. Schlosser, who graduated by passing rigorous exams and by defending their doctoral theses, which was not the case for Chytil as he,

\footnotetext{
${ }^{3}$ Adapted text of the contribution presented at the colloquium held on the occasion of the 85th anniversary of Chytil's death at the Institute of Art History CAS in Prague on 12 November 2019. The colloquium was instigated by Jana Marešová in relation to the termination of the processing of one part of Karel Chytil's estate, deposited in the Institute of Art History CAS. I owe my appearance at the colloquium to prof. PhDr. Lubomír Slavíček, CSc. Publication of the contribution was made possible by the university development project at the Faculty of Architecture at Brno University of Technology no. AD152012002.

${ }^{4}$ National Museum Archive in Prague, Karel Chytil fund, inventory no. 609.

${ }^{5}$ From 1887, Karel Chytil was a correspondent for Bohemia at the Vienna Central Committee, which dealt with heritage preservation. In 1903, he was appointed a conservationist of the second section of the committee for the districts of Čáslav, Chrudim, Litomyšl and Polička, and in 1909 he became a correspondent again. BRÜCKLER, Theodor, NIMETH, Ulrike (eds.): Personenlexikon zur Österreichischen Denkmalpflege (1850-1990). Wien, 2001, p. 40.

${ }^{6}$ The oldest department of art history in German-speaking countries was established in 1813 at the University of Göttingen, followed by Královec (1825, and from 1830 full professorship), Berlin (1844), Vienna (from 1852 extraordinary professor, from 1863 full professor), Bonn (1860), Strasbourg (1871), Leipzig (1872), Prague (1874), and Basel (1874). Other academic workplaces in German-speaking countries were generated later, for example, in Heidelberg, Freiburg im Breisgau, Nuremberg or Würzburg, etc. DILLY, Heinrich. Kunstgeschicbte als Institution. Studie zur Geschichte einer Dis₹iplin, Frankfurt am Main, 1979; KUMMER, Stefan. Die Anfänge der Kunstgeschichte an der Universität Würzburg. In: Anfänge der geschichtlichen Forschung an der Universität Würzburg. 150 Jahre Historisches Institut. 100 Jabre Kunstgeschicbtliches Institut. Historische Studien der Universität Würzburg, Mainfränkische Hefte 109, Regensburg, 2010, pp. 9-62.
} 
in spite of studying art history in Vienna, graduated in Prague. ${ }^{7}$ There were approximately 160 of them between 1872 and 1933, from Albert Ilg to Hans Gombrich. What is interesting about them is their careers either as lecturers or custodians of special libraries and art collections, which have their hierarchy. The first places to be occupied were imperial collections and picture galleries in Vienna or Berlin, and then the graduates spread to the peripheries which meant Frankfurt, Bonn and Galicia (a historical region between Central and Eastern Europe). The exceptions were private scholars like Vincenc Kramár, or members of the nobility, whose careers were not important for their financial security. This small group of prominent intellectuals, together with art history graduates from other schools, including both universities in Prague, represented the field of art history in Central Europe until the 1930s. Their public activity was proven not only by international art history congresses, because just as the community of historians divides itself in two professional groups-academics and museologists-they also searched for and found specific forms of professional activity directed inwards, towards the inside of the professionally closed community, as well as outwards, towards the public. As the end of the nineteenth century was approaching, more art history departments were emerging in German-speaking countries, as were public art museums, museums of decorative arts and galleries. A common field of both academics and museologists is science; in the case of science in a museum, it was fully within Wirth's intentions of the characterisation of Karel Chytil, who "built the first science-based and ordered department in the museum of decorative arts [within Czech land]." 8

It was, thus, the museum sphere as a specific society of its partakers - art historians who were professionally shaped in museology-into which Chytil was integrated. Art museums formed important cultural and explorational centers- the task now, however, was to interconnect them, to create a network among them, which was achieved by Austrian museums of decorative arts at the turn of the twentieth century. The uniqueness of these lies in the fact that they did not limit themselves to capital cities only-we can mention Liberec, Brno or Opava, because they had close and intensive connections due to the director of the museum of decorative arts in Brno, Julius Leisching (1865-1933), who was an outstanding organiser.' Those $^{-1}$ who partook in the work of museums of decorative arts, including Chytil, used to meet regularly — and we should not get confused by the seemingly banal nature of some of their events, which were distant compared to the "pure" art history. For example, Karel Chytil referred to the experience with showcases for expositional purposes at the congress in Opava in 1903. However, it is such public appearances in which the modern point of view is reflected: it is an artifact in an aggregate of a public collection - and that is mainly an issue of presentation and conservation, which were the two constituents of museology as it was seen back then. Its highly topical component at the time was the means of public enlightenment through the museum. ${ }^{10}$

If the word West is understood as the civilisation standard of that time, which had been pervading from England and France through German states to Austria, then the public care of

\footnotetext{
${ }^{7}$ SCHLOSSER, Julius von. Die Wiener Schule der Kunstgeschichte. Rückblick auf ein Säkulum deutscher Gelehrtenarbeit in Österreich. Innsbruck, 1934, pp. 213-226.

${ }^{8}$ WIRTH, Z. Karel Chytil, p. 663.

${ }^{9}$ KIRSCH, Otakar. Julius Leisching a jeho podíl na organizaci muzejnictví v Předlitavsku. In: Studia bistorica Brunensia 57, 2010, no. 1, pp. 15-29.

${ }^{10}$ The aspect of popular education was accentuated in the Czech museum environment in relation to the strong stimuli from outside, namely from Germany, c.f. ŽALUD, Augustin. Kulturní politika česká a musea. In: TOBOLKA, Zdeněk Václav: Česká politika 5. Kulturní, zulástě školské úkoly české politiky, Praha 1913, pp. 965-969.
} 
artistic artifacts and their collections represents that standard. This also includes professional magazines and various means of intellectual exchange, mainly congresses of museologists, but also refers to the German Association of Museum Workers in Defence Against Counterfeiting and Unfair Trade Practices, established in Hamburg in October 1897, and the talks which Chytil attended at that time as well as in later years. ${ }^{11}$ The arbiter of the work in museums of decorative arts in the Austrian and Czech lands was Johann II, Prince of Liechtenstein, and that is why the Austrian Museums Association gave him a plaque, which was awarded during an art competition, where Karel Chytil, as one of the judges, met with Julius Leisching, Karel Lacher and Edmund Wilhelm Braun. ${ }^{12}$ One of Central European museum director's duties from around 1900 was cooperation with industrialists and sole traders-potential patrons of museums and curatorium members - and interconnection of museum activity with the contemporary trends in industry and craft. From this point of view, attention is drawn by Chytil's talks on topics like On schools and industrial museums and their effects on industrial development and On the newest style directions in decorative arts at the meetings of Industrial union in Prague on 21 April $1885^{13}$ and 15 June $1894 .{ }^{14}$ A natural progression from this was participation in official projects, such as an edition of representative publications about the crown lands, Die Österreichisch-Ungarische Monarchie in Wort und Bild. ${ }^{15}$ The professionalisation of museum work itself belongs among western civilisation standards, which is evidenced by Chytil's student and later librarian in the National museum, Antonín Dolenský (1884-1956), who after coming back from a museum course in Bavaria wrote a groundbreaking text, Estetické požadavky modern muzeologie. ${ }^{16}$ Others among Chytil's students were even more interested in the questions of modern museology, namely Zdeněk Wirth and Jan Hofman. In their case, museology is connected with historic preservation and the attention here is drawn by Chytil's groundbreaking act of supporting a methodical list of sights according to German (sic) models. ${ }^{17}$ An art historian employed in a museum is a public issue, which is why we see Chytil's beginnings in a museum, his publications, exhibitions, ${ }^{18}$ lectures, ${ }^{19}$ career

\footnotetext{
${ }^{11}$ Verhandlungen der ersten Versammlung des Verbandes von Museums-Beamter zur Abwebr von Fälschungen und unlauterem Geschäftsgebahren, Hamburg [7-8 October 1898]. Neudruck, Juni 1908; Verhandlungen der ersten Versammlung des Verbandes von Museums-Beamter zur Abwebr von Fälschungen und unlauterem Geschäftsgebabren, Wien [24-25 September 1912].

12 ŠOPÁK, Pavel. Prostor pro umèní. Výtvarné umèni na Moravě a v českém Slezssku do roku 1918 jako téma bistorické muz̨eologie. Opava, 2016, p. 266.

${ }^{13}$ National Museum Archive in Prague, Karel Chytil fund, inventory no. 704, letters from the president of the Industrial union, J. Jeřábek to Karel Chytil from 15 April, 21 April and 24 April 1885.

${ }^{14}$ ANONYMOUS. Výroční valná hromada jednoty ku povzbuzení průmyslu v Čechách. In: Národni listy 34, 1894, no. 164, 16 June, p. 3. The manuscript from the lecture was preserved in Chytil's estate, see Museum of Decorative Arts in Prague, archive, Karel Chytil fund, inventory no. 77.

${ }^{15}$ Chytil's participation in the project, in relation to the tensions between the international and national elements in art history at the end of the nineteenth century, was noted by BAKOŠ, Ján. Paths and Strategies in the Historiography of Art in Central Europe. In: Ars 43, 2010, no. 1, p. 91.

${ }^{16}$ DOLENSKÝ, Antonín. Estetické požadavky moderní muzeologie. Dílo 11, 1913, pp. 161-179. The magazine of the Union of Creative Artists, called Dílo, undoubtedly focused on museums and picture galleries owing to Dolenský, who became an editor in the magazine during 1912.

${ }^{17}$ CHYTIL, Karel. O inventáŕi uměleckých památek. In: Osvěta 24, 1894, no. 8, pp. 717-727.

${ }^{18}$ For example, a reminder of the Retrospective exhibition held as part of the General Land Centennial Exhibition in Prague in 1981, published in Zeitschrift für christliche Kunst 5, 1892, no. 5, column 296.

${ }^{19}$ Among numerous public appearances, it is necessary to point out Chytil's lecture on Czech-Italian relations, which was given during the meeting of the Czech-Italian Association for Literature and Art at the Old Town Hall on 15 February 1914 in the presence of the Italian consul and other official guests. See ANONYMOUS. Česko-italské družstvo literární a umělecké v Praze. In: Čas 28, 1914, no. 57, 27 February, p. 7.
} 
advancement ${ }^{20}$, etc. in domestic magazines as well as in Austrian and German ones. On the contrary, a Prague museologist sees it as his responsibility to inform foreign countries about domestic affairs. ${ }^{21}$ Intellectual exchange among museums in Austria and Germany is evidenced by both short notes and longer messages in Chytil's estate written by Julius Lessing, Justus Brinckmann, Gustav Pazaurek, Karel Woermann, Josef Folnesics, Hermann von Trenkwald, Hans Seger, Jacob von Falke and some other colleagues of his. The Prague museum, and particularly its glass collection, was also familiarly described by Wilhelm von Bode. ${ }^{22}$ The civilising character of this organisational effort interconnects museums in the capitals of German and Austrian states with those in Chrudim, ${ }^{23}$ Hradec Králové, Plzeň or České Budějovice. Until the First World War, the exchange of news, organisation of travelling exhibitions, and sending of publications to museum libraries created a unique space for the realisation of modern museum work as an integral part of modern European civilisation. And it was this context of museum work in the field of decorative arts at the turn of the twentieth century which was described by Warburg in his abovementioned letter from 1927-similarly to other occasions, he addressed Edmund Wilhelm Braun and Ernst Schwedeler-Mayer, directors of leading countries in the field of decorative arts. ${ }^{24}$

By West I also mean research topics, and it was Chytil's teacher, Alfred Woltmann (18411880), who would determine the directions of Chytil's research interests ${ }^{25}$ - notionally as well as in actual fact-in his lecture entitled German Art in Prague on 25 November $1876^{26}$. One topic should be pointed out — as antiquarian as it may be-the topic of Prague junkers [free artists]. This was mentioned by Woltmann in his lecture, and also in a dissertation from 1879 written by Adolf Hammerschlag (1855-1879), one of Moritz Thausing's first graduates of art history, who before going to Vienna was Woltmann's and Benndorf's student at the University of Prague, similarly to Chytil. ${ }^{27}$ Therefore, Chytil could not a priori disregard this topic, although his book on Prague junkers was published much later. ${ }^{28}$ Chytil's pro-western orientation can also be seen in his artistic journalism and essays, for example, when he wrote for Lumir, a mag-

\footnotetext{
${ }^{20}$ For example, a notice about Karel Chytil being appointed a professor was published by Der Cicerone magazine. Halbmonatsschrift für die Interessen des Kunstforschers \& Sammlers 3, 1911, p. 109.

${ }^{21}$ C.f. Chytil's commentary on the opening of the Rudolfinum with the picture gallery of Patriotic Friends of the Arts Society. CHYTIL, Karel. Das Rudolphinum in Prag. In: Kunstchronik 20, 1884/1885, no. 21, column $357-361$.

${ }^{22}$ National Museum Archive in Prague, Karel Chytil fund, inventory no. 369, visiting card from 10 January 1896; inventory no. 747, Wilhelm von Bode's letters from 3 January 1894 and 19 January 1907.

${ }^{23}$ National Museum Archive in Prague, Karel Chytil fund, inventory no. 58, appointment to the function of a corresponding member of the curatorium at the Industrial museum for Eastern Bohemia in Chrudim.

${ }^{24}$ ŠOPÁK, Pavel. Aby Warburg píše Edmundu Wilhelmu Braunovi. In: Historia artium IV. Sborník k osmdesátým narozeninám prof. PhDr. Rudolfa Chadraby, CSc., ed. Pavol Černý, Olomouc, 2002, pp. 405-412.

${ }^{25}$ National Museum Archive in Prague, Karel Chytil fund, inventory no. 31, student's record book, lectures and seminars of Alfred Woltmann: Kunstgeschichtliche Übungen; Kunstgeschichtliche Denkmäler in Prag; Allgemeine Kunstgeschichte; Rubens, Rembrandt und ibre Zeit; Kunst des XIX. Jahrbunderts. C.f. the name of Karel Chytil's lecture Rubens and Rembrandt. Alois Jirásek remembered Woltmann's activity in Prague very positively. He also published a testimony of Czech students' protests against Woltmann. JIRÁSEK, Alois. Z mích pamětí. Litomyšl, 1932, pp. 12-16.

${ }^{26}$ WOLTMANN, Alfred. Deutsche Kunst in Prag. Ein Vortrag gehalten zu Prag am 25. November 1876, Leipzig, F. A. Seemann 1877. C.f. also THAUSSING, Moritz. Alfred Woltmann. In: Repertorium für Kunstwissenschaft 3, 1880, pp. 357-360; ANONYMOUS. Alfred Woltmann †. In: Deutsche Bauzeitung 14, 1880, no. 22, p. 117.

${ }^{27}$ ANONYMOUS. Dr. Adolf Hammerschlag. In: Montags-Revue aus Böhmen. Wochenschrift für Politik, Volkswirtschaft und Literatur (Prag) 1, 1879, no. 9, 2 July, p. 6.

${ }^{28}$ CHYTIL, Karel. O junkerech prašskeých. Praha: Nákladem České akademie císaře Františka Josefa pro vědy, slovesnost a umění 1903.
} 
azine connected with Jaroslav Vrchlický and Julius Zeyer. ${ }^{29}$

However, it was primarily the world of museums that compensated Chytil for what he was deprived of at the very beginning, when he did not pass the habilitation colloquium ${ }^{30}$ on 12 July 1883, and he became a docent [associate professor] fourteen years later. After all, his two exhibitions about Rudolf II (1904 and 1912) were rightly acclaimed in German and Austrian professional periodicals and they were undoubtedly the most successful exhibition projects which got beyond the Czech borders owing to German catalogues, which ensured proper publicity to all those exclusive exhibits. ${ }^{31}$

Before we get to the "post-coup" Chytil, it is also necessary to mention the East from the title, with particular reference to the era of the First World War, or more precisely the era until 1918. Here it is important to point out a photo of a young Karel Chytil in a Montenegrin folk costume preserved in his estate, ${ }^{32}$ and all the associations it arouses, from Montenegrin themes in the paintings of Jaroslav Čermák, Slavic themes in the works and translations of Josef Holeček and other personages of the Czech literary and artistic culture who were attracted by the Slavic south. Based on Chytil's publications in Dílo magazine, it can be inferred that it is necessary to think about opinions close to the Union of Creative Artists, which was presented as an artificial corporation establishing contacts with the Slavic world. Chytil's participation in the protection of the old Prague, which was facing the construction of new buildings in a historic environment as well as redevelopment, was situated in the anti-Viennese context by the conservative circles, as evidenced by the words of Jan Lier (1852-1917) who said that the historism of Prague's streets and squares is "imported from abroad, limited by perfectionism of styles." 33 Even Chytil's leading position in the museum of decorative arts was embroiled among national disputes, since the German press did not like that a Czech scholar was leading the museum.

He remained faithful to the museum of decorative arts until $1916^{34}$. Two years later there was a completely different Chytil within the new structures of a modern state-for one thing, a university had replaced the museum of decorative arts in his life, and for another, his social activities had broadened significantly and were shaped by his membership of a political party, the National Democracy. The party was building on a principle of elitism, as it was presenting itself as the elite of the Czech right wing, and gathering affluent people mainly from financial spheres. Their leader was Karel Kramár. This fact reminds us of the second pole in the title of this text, the East.

Firstly, a note on the West: for the interwar Czechoslovakia it was represented primarily by France, the attention of which was drawn by the international congress on the history of art in Paris in 1921. František Žákavec (1878-1937), as one of the five Czechoslovak delegates, gave one of the opening speeches in which he accentuated the relationship of the Czech lands to France. At this congress, to which German, Austrian and Hungarian art historians were not

\footnotetext{
${ }^{29}$ CHYTIL, Karel. Svatí tři králové v umění výtvarném. In: Lumír 12, 1884, no. 3, pp. 36-41.

${ }^{30}$ National Museum Archive in Prague, Karel Chytil fund, inventory no. 44 and 45.

${ }^{31}$ From reactions, for example, FRIMMEL, Theodor von. Karel Chytil—Die Kunst in Prag zur Zeit Rudolf II. In: Blätter für Gemäldekunde 2, 1906, no. 3, pp. 63-64.

32 The photography was presented by Jana Marešová during her contribution at the Chytil colloquium.

${ }^{33}$ LIER, Jan. Prof. Dr. K. Chytil vydal..., In: Zvon 16, 1916, no. 51, p. 715.

${ }^{34} \mathrm{He}$ always followed issues of museum work, which documents a paper on an exhibition of confiscated bells, see CHYTIL, Karel. O zvonech. In: Zvon 18, 1918, pp. 35-36.
} 
invited, Chytil spoke about Prague Castle under the Luxembourg dynasty. ${ }^{35} \mathrm{He}$ presented similarly symbolic topics on various occasions after 1918. He was, for example, one of the first people to be interested in the design of the Bethlehem Chapel, ${ }^{36}$ and he also published a work at the beginning of 1918 called Česká koruna královská, which was commented on by Národní listy [a national newspaper] and which stated that it will be appreciated mainly by those "for whom the Czech crown has never lost and never will lose its validity." ${ }^{37}$ It is important to realise that such texts were written when the idea of an independent state was already talked about, but its later form of a republic was not yet on the agenda. The cultural political consequences of Chytil's texts suited National Democracy's state-forming ambitions. It is no surprise that it was Chytil who was behind the founding of the Czechoslovak military museum, the programme of which was based on French models, ${ }^{38}$ and he was also a founding member of Společnost musea Husova [Society of the Hus Museum] (1920), ${ }^{39}$ which was preceded by his participation in a Hus exhibition held by the Czech university in 1915, and his involvement in the catalogue which was published on the occasion. ${ }^{40}$ Attacks against Viennese centralism were a natural thing at that time and they appeared in evaluations of the pre-coup conditions and perspectives of historic preservation. ${ }^{41}$

In this sense, we see the symbolic West from the title in a new political situation; nevertheless, the duty of Czech art history is to observe the Slavic east, just as required by Chytil in his well-known lecture about art historians' responsibilities in the new state. ${ }^{42}$ And it was Slovansky výbor [the Slavic committee] in Paris which stated in the declaration from May 1919 that "after the world war a new Slavic era begins!" (As a matter of interest, this declaration was co-signed by painter František Kupka). ${ }^{43}$ Symbolically, Karel Chytil was one of the people who were instrumental in the arrival of Nikodim Pavlovič Kondakov (1844-1925) at the Czech university in Prague, and he also gave the main speech on the occasion of Kondakov's eightieth birthday. ${ }^{44}$ A comparison, as simple as it may be, suggests itself here. If Chytil in the pre-coup era found devoted young adherents of modern trends in museology based on the German and Austrian models, in this later period he found equally devoted followers of the European east. One of

\footnotetext{
${ }^{35}$ SIBLÍK, Emanuel. Mezinárodní sjezd dějepisců umění v Pařiži. In: Národní listy 61, 1921, no. 267, 29 September, p. 5. On Chytil's relationship with France see also CHYTIL, Karel. Ze studijní cesty po Francii roku 1925. In: Ročenka Krubu pro pèstováni dějin umèni za rok 1926 a 1927. Praha, 1928, pp. 91-111.

${ }^{36}$ CHYTIL, Karel. K otázce podoby kaple betlemské. In: Zlatá Praha 37, 1919, no. 7-8, p. 62; no. 15-16, pp. $124-126$.

${ }^{37}$ ANONYMOUS. Dr. Karel Chytil—Česká koruna královská. In: Národní listy 58, 1918, no. 25, 30 January, p. 3.

38 ANONYMOUS. Zakládání nových muzeí. In: Národni listy 61, 1921, no. 226, 19 August, p. 4; TSCHORN, R. Československé vojenské museum. In: Česká revue 16, 1923, no. 8-9, pp. 358-363. National Museum Archive in Prague, Karel Chytil fund, inventory no. 74, appointment to a member of the museum department of the Czechoslovak Military Institute of Science, 20 June 1920.

${ }^{39}$ National Museum Archive in Prague, Karel Chytil fund, inventory no. 73, appointment to a founding member from 29 April 1920.

${ }^{40}$ V. F. Na pětisetletou pamět' mučednické smrti Husovy..., In: Zvon 15, 1915, no. 49, 3 September, pp. $686-687$.

${ }^{41}$ CHYTIL, Karel. Finis vídeňského c. k. Denkmalamtu. In: Cesta 1, 1919, pp. 794-796.

${ }^{42}$ CHYTIL, Karel. O př́štích úkolech dějin a historiků umění v československém státě. In: Naše doba. Revue pro vědu, umèni a život sociálni 26, 1919, pp. 48-757. A paper; see TLAMICH, Zdeněk. Úkol dějin a historiků umění v československém státě. In: Cesta 1, 1918-1919, p. 1028.

${ }^{43}$ Prohlášení Slovanského výboru v Paříži. In: Národní listy 63, 1919, no. 137, 20 May, p. 1.

${ }^{44}$ Oslava 80. narozenin prof. N. P. Kondakova. In: Národní listy 64, 1924, no. 302, 1 November, p. 5. C.f. also CHYTIL, Karel. O životě a vědecké práci Nikodema Pavloviče Kondakova. In: Památky archeologické 34, 1924, pp. 189-205; Id. Dr. Nikodem Pavlovič Kondakov. Nekrolog. In: Almanach české akademie véd a uméni 36. Praha, 1926, pp. 89-205.
} 
them, for example, was Jaroslav Nebeský (1892-1937), but he, like many others, did not earn his living at a university or in a museum. He worked as an officer at the Ministry of Foreign Affairs, where he was able to use his knowledge of many Slavic languages. ${ }^{45}$ The aforementioned Žákavec developed a different approach to the Slavic east and Czech national traditions. He differed from his contemporaries by understanding the relationship between East and West as a balance between two poles, in the imaginary intersection of which lay the contemporary Czechoslovak art. These aspects, of course, had their methodological consequences, as Marta Filipová pointed out in her study some time ago; ${ }^{46}$ however, East does not cease to be an important cultural political symbol — a symbol of experiencing patriarchal Slavic Rus, as acclaimed by Alfons Mucha. Chytil popularised Mucha's cycle through his texts and lectures. ${ }^{47}$ This East was, in the 1920s and 1930s, predominantly an illusion. We can use an effective parallel here: it is known that Karel Kramár enthused about the formation of an army which would rid Russia of communism, which was surely illusory, similar to the mythical deities in Mucha's mythological compositions which were supposed to belong to the modern world.

\section{References}

\section{Archival Sources}

National Museum Archive in Prague, Karel Chytil fund

\section{Literature}

ANONYMOUS (1880). Alfred Woltmann. In: Deutsche Bauzeitung 14, no. 22, p. 117.

ANONYMOUS (1914). Cesko-italské družstvo literárni a umělecké v Praze. In: Čas 28, no. 57, 27 February, p. 7.

ANONYMOUS (1879). Dr. Adolf Hammerschlag, Montags-Revue aus Böhmen. In: Wochenschrift für Politik, Volkswirtschaft und Literatur (Prag) 1, no. 9, 2 July, p. 6. ANONYMOUS (1918). Dr. Karel Chytil-Česká koruna královská. In: Národní listy 58, no. 25, 30 January, p. 3.

ANONYMOUS (1894). Výroční valná hromada jednoty ku povzbuzení průmyslu v Čechách. In: Národní listy 34, no. 164, 16 June, p. 3.

ANONYMOUS (1921). Zakládání nových muzeí. In: Národní listy 61, no. 226, 19 August, p. 4. BAKOŠ, Ján (2010). Paths and Strategies in the Historiography of Art in Central Europe. In: Ars 43, no. 1, p. 91.

BIRNBAUM, Vojtěch (1934). Prof. Dr. Karel Chytil. In: Casopis Společnosti prátel starožitnosti 42, pp. 142-143.

BRÜCKLER, Theodor, NIMETH, Ulrike (eds.) (2001). Personenlexikon zur Österreichischen Denkmalpflege (1850-1990), Wien, Berger \& Söhne. ISBN 978-3850283441

CHYTIL, Karel (1884/1885). Das Rudolphinum in Prag. In: Kunstchronik 20, no. 21, pp. 357361.

CHYTIL, Karel (1919). Finis vídeňského c. k. Denkmalamtu. In: Cesta 1, pp. 794-796.

\footnotetext{
${ }^{45}$ VANĚČEK, Jaroslav. Dr. Jaroslav Nebeský. In: Pod Blaníkem 16, 1936-1937, p. 144.

${ }^{46}$ FILIPOVÁ, Marta. Between East and West: The Vienna School and the Idea of Czechoslovak Art. In: Journal of Art Historiography no. 8, June 2013.

${ }^{47}$ ŠOPÁK, Pavel. Alfons Mucha píše Karlu Chytilovi. In: Opuscula bistoriae artium 67, 2018, no. 2, pp. $140-146$.
} 
CHYTIL, Karel (1919). Kotázce podoby kaple betlemské. In: Zlatá Praha 37, no. 7-8, p. 62; no. 15-16, pp. 124-126.

CHYTIL, Karel (1894). O inventáři uměleckých památek. In: Osvěta 24, no. 8, pp. 717-727.

CHYTIL, Karel (1919). O přrištích úkolech dějin a historiků umění v československém státě. In: Naše doba. Revue pro védu, umèni a život sociálni 26, pp. 48-757.

CHYTIL, Karel (1918). O zvonech. In: Zvon 18, pp. 35-36.

CHYTIL, Karel (1884). Svatí tři králové v umění výtvarném. In: Lumír 12, no. 3, pp. 36-41.

DILLY, Heinrich (1979). Kunstgeschichte als Institution. Studie zur Geschichte einer Disziplin, Frankfurt am Main. ISBN 978-3518075111

DOLENSKÝ, Antonín (1913). Estetické požadavky moderní muzeologie. In: Dílo 11, pp. 161_ 179.

FILIPOVÁ, Marta (2013). Between East and West: The Vienna School and the Idea of Czechoslovak Art. In: Journal of Art Historiography no. 8, June.

FRIMMEL, Theodor von (1906). Karel Chytil-Die Kunst in Prag zur Zeit Rudolf II. In: Blätter für Gemäldekunde 2, no. 3, pp. 63-64.

JIRÁSEK, Alois (1932). Z mích pamètí, Litomyšl.

KIRSCH, Otakar (2010). Julius Leisching a jeho podíl na organizaci muzejnictví v Předlitavsku. In: Studia historica Brunensia 57, no. 1, pp. 15-29.

KRÁSA, Josef (1986). Karel Chytil. In: CHADRABA, Rudolf-KRÁSA, Josef—ŠVÁCHA, Rostislav (eds.): Kapitoly z českébo dějepisu umèní 1, Praha, pp. 172-180.

KUMMER, Stefan (2010). Die Anfänge der Kunstgeschichte an der Universität Würzburg. In: Anfänge der geschichtlichen Forschung an der Universität Würæburg. 150 Jahre Historisches Institut. 100 Jahre Kunstgeschichtliches Institut, Historische Studien der Universität Würzburg, Mainfränkische Hefte 109, Regensburg, pp. 9-62.

LIER, Jan (2016). Prof. Dr. K. Chytil vydal... In: Zvon 16, no. 51, p. 715.

MATĚJČEK, Antonín (1935). Karel Chytil. In: Ročenka Krubu pro pěstováni déjin umèní za rok 1934. Praha, pp. 3-15.

SCHLOSSER, Julius von (1934). Die Wiener Schule der Kunstgeschichte. Rückblick auf ein Säkulum deutscher Gelehrtenarbeit in Österreich, Innsbruck, Wagner.

SIBLÍK, Emanuel (1921). Mezinárodní sjezd dějepisců umění v Pařiži. In: Národní listy 61, no. 267, 29 September, p. 5.

ŠOPÁK, Pavel (2002). Aby Warburg píše Edmundu Wilhelmu Braunovi. In: Historia artium IV. Sborník k osmdesátým narozeninám prof. PhDr. Rudolfa Chadraby, CSc., ed. Pavol Černý, Olomouc, pp. 405-412.

ŠOPÁK, Pavel (2018). Alfons Mucha píše Karlu Chytilovi. In: Opuscula bistoriae artium 67, no. 2, pp. 140-146.

ŠOPÁK, Pavel (2016). Prostor pro umèní. Výtvarné umèní na Moravě a v českém Slezsku do roku 1918 jako téma historické muzeologie, Opava, Slezské zemské muzeum. ISBN: 978-80-87789-38-4

THAUSSING, Moritz (1880). Alfred Woltmann. In: Repertorium für Kunstwissenschaft 3, pp. 357360.

TLAMICH, Zdeněk (1918/1919). Úkol dějin a historiků umění v československém státě. In: Cesta 1, p. 1028.

TSCHORN, R (1923). Československé vojenské museum. In: Česká revue 16, no. 8-9, pp. 358363. 
V. F. (1915). Na pětisetletou pamět' mučednické smrti Husovy.... In: Zvon 15, no. 49, 3 September, pp. 686-687.

VANĚČEK, Jaroslav (1936/1937). Dr. Jaroslav Nebeský. In: Pod Blaníkem 16, p. 144.

WIRTH, Zdeněk (1934). Karel Chytil. In: Umèní 8, no. 1, p. 8.; Id. Karel Chytil (2. VII. 1934). Ceský časopis historický 40, 1934, pp. 662-664.

WOLTMANN, Alfred (1877). Deutsche Kunst in Prag. Ein Vortrag gehalten zu Prag am 25. November 1876, Leipzig, F. A. Seemann. ISBN: 978-5878621076

ŽALUD, Augustin (1913). Kulturní politika česká a musea. In: TOBOLKA, Zdeněk Václav. Ceská politika 5. Kulturní, zulástě školské úkoly české politiky. Praha, pp. 965-969. 